\begin{tabular}{c}
\hline ALFABETA: Jurnal Bahasa, Sastra, dan \\
Pembelajarannya \\
ISSN:2654-2587 (Print); ISSN:2654-735X (Online) \\
Volume 3, Nomor 1, Tahun 2020, Hal. 63-69 \\
Available online at: \\
http://ejurnal.budiutomomalang.ac.id/index.php/alfabeta \\
\hline
\end{tabular}

\title{
Research Article \\ PENGUASAAN BAHASA DALAM KOMUNIKASI LISAN ANAK AUTIS DI UPT PENDIDIKAN ABK MALANG
}

\author{
Lidia Kurniasari ${ }^{1}$, Endang Sumarti ${ }^{2}$, Azza Aulia Ramadhani ${ }^{3}$ \\ Pendidikan Bahasa dan Sastra Indonesia IKIP Budi Utomo Malang \\ lidiakurniasari24@gmail.com ${ }^{1}$, endangsumarti@yahoo.com ${ }^{2}$, \\ azzauliaramadhani@gmail.com ${ }^{3}$
}

\begin{tabular}{ll}
\hline Informasi Artikel & \multicolumn{1}{c}{ ABSTRACT } \\
\hline Submit: $29-3-2020$ & This study aims to determine the types of words, phrases, and \\
Diterima: $13-4-2020$ & sentences that are controlled by autistic children in Malang ABK \\
Dipublikasikan: $15-4-2020$ & Education Unit. Words, phrases, sentences mastered by autistic \\
& children are grouped by type according to their characteristics. \\
& The formulation of the problem in this study is how is the \\
& mastery of words, phrases, and sentences, as well as the function \\
& of word, phrases, and sentences spoken by autistic children in \\
& their communication orally. The type of words studied are \\
& nouns, work, properties, and numbers. The types of phrases \\
& examined are noun phrases, verbs, and adjectives. The sentences \\
& studied are statement sentences, questions, and commands. This \\
& research is qualitative research. Data obtained from \\
& observations, recordings, and documents on the activities of \\
& autistic children in school and outside school in form of oral \\
& data, the converted into written data through the transcription \\
process. The results of this study are (1) research subjects are & more mastering nouns with the number of words spoken as many \\
& as 32 words, (2) the types of phrases that are more mastered are \\
& noun phrases with a number of phrases as many as 10 phrases, \\
& (3) types of sentences that are more controlled by the subject \\
& research is a statement sentence with number of sentences as \\
& many as 24 sentences, and (4) the most dominant language \\
function in the pronunciation of words, phrases, and sentences is & an informative function, the function tells something he knows. \\
Keywords: language mastery, oral communication, \\
autic
\end{tabular}


kualitatif. Data yang diperoleh dari observasi, rekaman, dan dokumen kegiatan anak autis di sekolah dan luar sekolah berupa data lisan, kemudian diubah menjadi data tulisan melalui proses transkripsi. Hasil dari penelitian ini: (1) subjek penelitian lebih menguasai kata benda dengan jumlah kata yang diucapkan sebanyak 32 kata, (2) jenis frasa yang lebih dikuasai adalah frasa nomina dengan jumlah frasanya sebanyak 10 frasa, (3) jenis kalimat yang lebih dikuasai oleh subjek penelitian adalah kalimat pernyataan dengan jumlah kalimat sebanyak 24 kalimat, dan (4) fungsi bahasa yang paling dominan dalam pengucapan kata, frasa, dan kalimat adalah fungsi informatif, atau fungsi untuk memberitahukan sesuatu yang diketahuinya.

Kata kunci: penggunaan bahasa, komunikasi lisan, autis

\section{PENDAHULUAN}

Penguasaan bahasa adalah kemampuan seseorang dalam hal menguasai suatu bahasa, baik dalam bahasa lisan maupun tulisan guna menyampaikan pikiran atau gagasannya. Menurut MacTruck dan Morgan (dalam Puitika, 2015:84) "mastery is great skillfulness and knowledges of some subject or activity". Penguasaan bahasa adalah sebuah kecakapan seseorang terhadap pengetahuan bahasa dan dapat mengaplikasikannya dalam aktivitas berbahasa. Dapat dikatakan bahwa seseorang dapat dikatakan memiliki penguasaan bahasa yang baik jika proses reseptif dan produktifnya baik.

Penguasaan bahasa dipengaruhi oleh faktor kesehatan dan usia seseorang. Salah satu gangguan kesehatan kognitif yang mempengaruhi penguasaan bahasa seseorang adalah autis. Gangguan kognitif anak autis berpengaruh terhadap praktik pemrosesan informasi danketerampilan mereka dalam berkomunikasi (Sumarti, 2017). Anak autis mengalami gangguan kualitatif dalam komunikasi dan interaksi sosial (Peeters, 2004). Sejalan dengan pendapat di atas, Puspita (2008) menyatakan bahwa kemampuan kominikasi untuk dapat mengungkapkan diri dengan efektif dan efisien sangat terbatas. Anak autis tidak mampu mengekspresikan keinginannya secara spontan (Prasetyono, 2008).

Autis adalah sebuah gangguan pada perkembangan anak yang dapat mengakibatkan buruknya komunikasi, ekspresi diri, dan hubungannya dengan orang lain. McCandless (2003:5) meyatakan bahwa terdapat dua jenis autis, yaitu autis sejak lahir (klasik) dan autis yang sindromnya mulai muncul pada tahu kedua kelahiran seseorang (regresif). Pada perbedaan usia, anak-anak normal dengan usia 4 tahun telah mampu merangkai kalimat yang terdiri atas 4 s.d. 5 kata, bercerita dengan baik, menanyakan arti suatu kata, dan berhitung mencapai angka 20. Berbeda dengan itu, anak autis dengan usia 4 tahun masih saja tidak mampu berbicara, atau hanya melakukan pengulangan kata yang didengarnya (ekolalia) tanpa mengetahui arti atau makna yang sebenarnya. Beberapa anak autis tidak mampu berbicara, tidak mampu mengekspresikan diri baik mlalui bahasa verbal maupun non verbal (Sumarti, 2015). Anak autis memiliki perilaku repetitif dan stereotif dalam penggunaan bahasa (Priyatna, (2010) dan Veskarisyanti (2010). Kesulitan anak-anak autis dalam berbahasa jug memengaruhi kemampuannya dalam bidang komunikasi, imajinasi, dan sosialisasi. Keempat bidang tersebut saling mempengaruhi satu sama lain, oleh karena itu pembelajaran bagi anakanak autis di rumah atau di sekolah lebih banyak menggunakan cara lisan. Hal itu disebabkan, anak-anak dengan gangguan autis akan lebih sering mendengarkan perintah orang lain, mengulangnya, atau menyebutkan bahasa yang mengacu pada benda di sekitarnya dan 
memiliki pengalaman langsung dengan benda tersebut. Salah satu contohnya yaitu ada sebuah peristiwa seperti berikut.

(Peristiwa: Di sekolah autis terdapat sebuah pengajaran dengan menggunakan kartu bergambar dan salah satu gambarnya adalah sebuah apel). Anak autis tersebut akan berbicara setelah melihat buah tersebut. "Apel" (dengan menunjukkan kartu bergambar sebuah apel).

Peristiwa tersebut menunjukkan bahwa anak autis akan dengan mudah mengucapkan kata "apel" karena subjek tersebut mempunyai suatu pengalaman memakan atau melihat apel sebelumnya. Berbeda jika subjek lain tidak pernah memiliki sebuah pengalaman pribadi mengenai sebuah apel, maka tidak akan didapati sebuah respons yang sama pada saat subjek tersebut melihat gambar sebuah apel.

Penelitian ini membahas bahasa berupa kata, frasa, dan kalimat yang diucapkan oleh anak-anak autis di UPT Pendidikan ABK Malang. Kata yang dimaksud berupa kata benda, kata kerja, kata sifat, dan kata bilangan. Frasa yang dimaksud adalah frasa nomina, frasa verba, dan frasa adjektiva. Kalimat yang dimaksudkan adalah kalimat pernyataan, klimat pertanyaan, dan kalimat perintah. Pemilihan beberapa jenis kategori kata, frasa, dan kalimat tersebut atas dasar bahasa yang diucapkan oleh anak autis selalu dekat dengan keseharian.

Setiap bahasa yang dikuasai oleh anak-anak autis pasti memiliki fungsi yang berbedabeda. Menurut Nababan (1991:44-45) ada delapan fungsi yang menjelaskan hubungan bahasa ketika digunakan dalam berkomunikasi secara perorangan, yaitu fungsi instrumental (meminta sesuatu), menyuruh (mengungkapkan keinginan menyuruh orang lain berbuat sesuatu), interaksi (pernyataan atau pertanyaan pencipta suasana), kepribadian (pernyataan mengakhiri peranan pribadinya), pemecahan masalah (meminta atau menyatakan jawaban atas sesuatu), khayalan (ungkapan untuk mempengaruhi pendengar), dan informatif (mengungkapkan hal yang diketahuinya). Sebagai contoh, anak autis yang menyebutkan kata "Apel", dapat memiliki maksud memberikan informasi bahwa buah tersebut bernama apel (informatif) atau sedang meminta sebuah apel (instrumental).

Anak penyandang autis memiliki kemampuan berkomunikasi yang istimewa bila dibanding dengan anak-anak pada umumnya. Dengan dimikian diperlukan perlakuan yang berbeda pula bila ingin berinteraksi dengan anak penyandang autisme. Oleh karena itu, wujud komunikasi anak penyandang autis ini perlu diuraikan agar orang-orang di sekitar lebih peka dalam menghadapi anak penyandang autisme.

Berdasarkan paparan di atas, maka peneliti melakukan sebuah penelitian tentang penguasaan bahasa anak-anak dengan gangguan autis dalam wujud komunikasinya secara lisan di kelas dan luar kelas. Sulitnya anak-anak autis berkomunikasi secara lisan, serta penguasaan bahasa yang dihasilkan oleh anak autis satu dengan yang lainnya pun berbedabeda, menjadi dua alasan utama peneliti tertarik meneliti "Penguasaan Bahasa dalam Komunikasi Lisan Anak Autis di UPT Pendidikan ABK Malang”.

\section{METODE PENELITIAN}

Penelitian ini menggunakan metode kualitatif dengan menyajikan data berupa deskripsi data. Pernyataan tersebut diperkuat oleh pendapat Muhadjir (dalam Mahsun, 2005:50) yang menyatakan bahwa penelitian kualitatif adalah penelitian yang mengutamakan proses, makna, atau persepsi pada saat penelitian berlangsung dengan menggunakan sistem deskripsi analisis yang teliti, namun masih dapat menerima data-data kuantitatif berbentuk angka atau jumlah dari sesuatu. Data didapatkan dengan menggunakan teknik triangulasi, yaitu teknik yang di dalam proses penelitian menggunakan tiga teknik sekaligus, yaitu teknik

Lidia Kurniasari, Endang Sumarti, Azza Aulia Ramadhani

- PENGUASAAN BAHASA DALAM KOMUNIKASI LISAN ANAK AUTIS DI UPT 
observasi, wawancara, dan dokumen (Sugiyono, 2015:241). Melalui tiga teknik gabungan tersebut, data yang didapatkan oleh peneliti berupa data lisan, kemudian peneliti melakukan proses transkripsi untuk mengubahnya menjadi data tulisan.

Instrumen penelitian merupakan alat yang digunakan oleh peneliti dalam proses mengumpulkan data selama penelitian berlangsung. Peneliti dalam penelitian ini merupakan instrumen utama penelitian, karena peneliti menetapkan fokus penelitian, memilih informan sebagai sumber data, mengumpulkan data, menilai kualitas data, menganalisis data, menagsirkan data, dan membuat kesimpulan atas semuanya (Sugiyono, 2015:222). Instrumen lain yang digunakan oleh peneliti dalam penelitian ini adalah tabel reduksi data dan kodefikasi transkrip percakapan. Tabel reduksi data digunakan untuk mengklasifikasikan bahasa yang diucapkan oleh subjek penelitian. Tabel kodefikasi transkripsi percakapan digunakan untuk mempermudah pengkodean pada saat memaparkan kutipan-kutiapan. Setelah data direduksi dan dikodefikasi, data-data tersebut disajikan dalam bentuk kutipan dan deskripsi naratif berupa paparan alasan berdasar teori yang telah disebutkan sebelumnya.

\section{HASIL DAN PEMBAHASAN}

Jenis-jenis bahasa yang dikuasai oleh anak-anak autis di UPT Pendidikan ABK Malang pada saat melakukan komunikasi lisan di dalam kelas maupun di luar kelas adalah sebagai berikut.

Tabel 1. Temuan Jenis Bahasa yang Dikuasai Anak Autis

\begin{tabular}{|c|c|c|c|}
\hline No & Kategori & Jenis & Hasil Temuan \\
\hline \multirow[t]{4}{*}{1} & \multirow[t]{4}{*}{ Kata } & Kata Benda & $\begin{array}{l}\text { Zazu, Abil, Islam, Rumahku, Mama, Adek, Allah, Emosi, } \\
\text { Mata, Argentina, Malaysia, Yunani, Athina, Mesir, Kairo, } \\
\text { Kanada, Pipi, Rambut, Hair, Tangan, Head, Kepala, Eyes, } \\
\text { Nose, Nyamuk, Perempuan, Jaket, Kamis, Kunci, Ungu, dan } \\
\text { Mami. }\end{array}$ \\
\hline & & Kata Kerja & Sholat, Dengarkan. Hitung, Naik, Jemur, dan Goyang. \\
\hline & & Kata Sifat & Syantik dan Sweet \\
\hline & & $\begin{array}{c}\text { Kata } \\
\text { Bilangan }\end{array}$ & $\begin{array}{l}\text { Dua puluh satu, Satu, Dua, Tiga, Empat, Lima, Enam, } \\
\text { Tujuh, Delapan, Sembilan, dan Sepuluh. }\end{array}$ \\
\hline \multirow[t]{3}{*}{2} & \multirow[t]{3}{*}{ Frasa } & $\begin{array}{c}\text { Frasa } \\
\text { Nomina }\end{array}$ & $\begin{array}{l}\text { Nama panjang, Bekasi Kuning, Puli Dua, Mama Dewi, } \\
\text { Tangal lahi, Agama Islam, Ibukota Argentina, Kuala } \\
\text { Lumpur, Korea Selatan, dan Rumah Mami. }\end{array}$ \\
\hline & & Frasa Verba & Sebelum tidur, sebelum makan, dan pakai helm. \\
\hline & & $\begin{array}{c}\text { Frasa } \\
\text { Adjektiva }\end{array}$ & Ramai sekali, sangat senang, dan lama sekali. \\
\hline \multirow[t]{3}{*}{3} & \multirow[t]{3}{*}{ Kalimat } & $\begin{array}{l}\text { Kalimat } \\
\text { Pernyataan }\end{array}$ & $\begin{array}{l}\text { Kitab suci Al-Quran, Abil pakai jaket, Abil pakai helm, Ke } \\
\text { rumah mami, Terimama kasih mas Abil, Siti Badriah } \\
\text { syantik, Abil mau ke Irak, Abil ke Korea, Abil berangkat ke } \\
\text { mami, Abil ke sekolah. }\end{array}$ \\
\hline & & $\begin{array}{l}\text { Kalimat } \\
\text { Pertanyaan }\end{array}$ & Sapa?, Sholat dimana? Mana syantik? \\
\hline & & $\begin{array}{l}\text { Kalimat } \\
\text { Perintah }\end{array}$ & hutdown! \\
\hline
\end{tabular}

Sebuah bahasa termasuk dalam kategori kata, frasa, atau kalimat karena sesuai dengan makna dari masing-masing kategori bahasa tersebut. Berikut adalah uraian rinci hasil temuan pada tabel di atas, dengan berdasar pada teori-teori yang ada. 


\section{Penguasaan Kata dalam Komunikasi Lisan Anak Autis di UPT Pendidikan ABK Malang}

Suatu bahasa dikatakan sebagai kata karena termasuk dalam satuan bahasa terkecil yang dapat berdiri sendiri, dapat diucapkan dalam bentuk yang bebas, dan bermakna (Muslich, 2010:4-5). Adaempatjenis kata yang didapatkan dalam penelitian ini, yaitu kata benda, kerja, sifat, dan bilangan. Setelah diteliti, subjek penelitian lebih dominan mengucapkan atau menguasai kata benda dengan jumlah 32 kata yang dikuasai.

Pertama, penguasaan kata benda.Salah satucontohnya, kata "kunci" termasuk dalam kata benda karena dapat dinegatifkan dengan kata "bukan", menjadi "bukan kunci". Selain itu, kata "kunci" dapat diikuti oleh kata ganti kepunyaan menjadi "kunciku".

Kedua, penguasaan kata kerja.Salah satucontohnya, yaitu kata "hitung" termasuk dalam kata kerja karena sering dilekati imbuhan "ber-" menjadi "berhitung". Selain itu, kata "hitung" dapat pula diperluas dengan kata "dengan+kata sifat" menjadi "hitung dengan teliti".

Ketiga, penguasaan kata sifat.Contohnya, kata "cantik" termasuk dalam kata sifat karena dapat diulang dan dilekati imbuhan "se-nya" menjadi "secantik- cantiknya". Selain itu, kata "cantik" dapat memberikan suatu sifat kepada benda, seperti "lukisan itu sangat cantik".

Keempat, penguasaan kata bilangan.Misalnya, kata "dua" dapat menyatakan jumlah, himpunan, atau urutan.

\section{Penguasaan Frasa dalam Komunikasi Lisan Anak Autis di UPT Pendidikan ABK Malang}

Bahasa dapat dikatakan sebagai frasa karena bentuk perluasan dari kata, tetapi antarunsurnya masih berada pada tataran sintaksis yang sama dan tetap berhubungan secara fungsional (Khairah dan Ridwan, 2014:20-21). Terdapat tiga jenis frasa yang didapatkan dalam penelitian ini, yaitu frasa nomina, frasa verba, dan frasa adjektiva. Frasa paling dominan diucapkan atau dikuasai oleh subjek penelitian dengan jumlah 10 frasa, adalah frasa nomina.

Pertama, penguasaan frasa nomina.Contohnya, frasa "nama panjang" memiliki unsur inti berupa kata benda, yaitu "nama". Unsur gabungannya adalah kata sifat, yaitu "panjang".

Kedua, penguasaan frasa verba.Salah satucontohny, frasa "sebelum makan" memiliki unsur inti berupa kata kerja, yaitu kata "makan". Unsur gabungannya merupakan unsur aspek, yaitu "sebelum".

Ketiga, penguasaan frasa adjektiva.Misalnya, frasa "lama sekali" dengan unsur inti kata sifat, yaitu "lama". Unsur gabungannya menyatakan suatu tingkatan, yaitu "sekali".

\section{Penguasaan kalimat dalam komunikasi lisan anak autis di UPT Pendidikan ABK Malang}

Bahasa dapat dikatakan sebagai kalimat karena diakhiri dengan lagu akhir selesai turun atau naik (Wijana, 2011:95). Terdapat tiga jenis kalimat yang ditemukan dalam penelitian ini, yaitu kalimat pernyataan, pertanyaan, dan perintah. Kalimat yang paling dominan diucapkan atau dikuasai oleh subjek penelitian adalah kalimat pernyataan dengan jumlah 24 kalimat.

Pertama, penguasaan kalimat pernyataan.Misalnya, kalimat "Abil pakai helm" menyatakan bahwa subjek penelitian memakai helm.

Kedua, penguasaan kalimat pertanyaan.Salah satucontohnyaadalah kalimat "mana syantik?" menyatakan bahwa subjek bertanya tentang keberadaan "syantik".

Lidia Kurniasari, Endang Sumarti, Azza Aulia Ramadhani

- PENGUASAAN BAHASA DALAM KOMUNIKASI LISAN ANAK AUTIS DI UPT 
Ketiga, penguasaan kalimat perintah.Contohnya, kalimat "shutdown!". Menyatakan suatu perintah untuk mematikan laptop.

\section{Fungsi Bahasa yang Diucapkan Anak Autis dalam Komunikasi Lisan di UPT Pendidikan ABK Malang}

Fungsi bahasa adalah kegunaan bahasa yang mengarah pada keperluan-keperluan bahasa yang digunakan oleh manusia. Terdapat delapan fungsi bahasa yang berhubungan dengan hubungan komunikasi lisan seseorang, yaitu fungsi instrumental, menyuruh, interaksi, kepribadian, pemecahan masalah, khayal, dan informasi. Fungsi bahasa yang peling dominan dalam pengucapan kata, frasa, atau pun kalimat dalam komunikasi lisan anak-anak autis di UPT Pendidikan ABK Malang ini adalah fungsi informatif. Anak-anak autis hanya sekadar memberikan informasi tentang suatu hal.

\section{SIMPULAN}

Berdasarkan hasil analisis dan pembahasan, terdapat empat hal yang dapat menjadi poin utama dalam penelitian tentang "Penguasaan Bahasa dalam Komunikasi Lisan Anak Autis di UPT Pendidikan ABK Malang". Empat hal yang menjadi poin utama dalam penelitian ini dapat disimpulkan sebagai berikut. Pertama, penguasaan kata dalam komunikasi lisan anak autis di UPT Pendidikan ABK Malang meliputi kata benda, kerja, sifat, dan bilangan. Kata yang paling dominan adalah kata benda, sebanyak 32 kata. Contoh dari kata benda di antaranya, Zazu, Abil, Jaket, dan Argentina. Kedua, penguasaan frasa dalam komunikasi lisan anak autis di UPT Pendidikan ABK Malang meliputi frasa nomina, verba, dan adjektiva. Frasa yang paling dominan adalah frasa nomina, sebanyak 10 frasa. Contoh dari frasa nomina di antaranya adalah nama panjang, Puli Dua, dan Bekasi Kuning. Ketiga,penguasaan kalimat dalam komunikasi lisan anak autis di UPT Pendidikan ABK Malang meliputi kalimat pernyataan, pertanyaan, dan perintah. Kalimat yang paling dominan adalah kalimat pernyataan, sebanyak 24 kalimat. Contoh dari kalimat pernyataan sebagai berikut Abil ke rumah mami dan Abil pakai jaket. Keempat,fungsi bahasa yang paling dominan dalam penelitian ini adalah fungsi informatif, atau fungsi yang memberikan informasi tentang hal yang diketahuinya.

\section{RUJUKAN}

Khairah dan Ridwan. 2014. Sintaksis: Memahami Satuan Kalimat Perspektif Fungsi. Jakarta: PT Bumi Aksara.

Mahsun. 2005. Metode Penelitian Bahasa: Tahapan strategi, Metode, dan Tekniknya. Jakarta: PT Raja Grafindo Persada.

McCandless, Jaquelyn. 2003. Children with Straving Brains, Anak-anak dengan Otak yang Lapar: Panduan Penanganan Medis untuk Penyandang Gangguan Spektrum Autisme. Jakarta: PT Grasindo.

Muslich, Masnur. 2010. Tata Bentuk Bahasa Indonesia: Kajian ke Arah Tata Bahasa Deskriptif. Jakarta: PT Bumi Aksara.

Nababan. 1991. Sosiolinguistik: Suatu Pengantar. Jakarta: PT Gramedia Pustaka Utama.

Peeters, T. 2004. Autisme: HubunganPengetahuan Teoretis, dab Intervensi Pendidikan Bagi Penyandang Autis. Jakarta: Dian Rakyat.

Prasetyono, D.S. 2008. Serba serbi anak autis (Autisme dan Gangguan Psikologis lainnya: mengenal, menangani, dan mengatasinya dengan tepat dan baik). Jogjakarta: DIVA Press. 
Priyatna, A. 2010. Amazing Autism: memahami, Mengasuh, dan Mendidik Anak Autis. Jakarta: Gramedia.

Puspita, D. 2008. Warna-warni Kehidupan: Ketika Anak Autis Berkembang Remaja. Jakarta: Yayasan Autisme Indonesia.

Sugiyono. 2015. Metode Penelitian Kuantitatif, Kualitatif, dan R\&D. Bandung: Alvabeta, CV. Sumarti, E. 2017. Gangguna Komunikatif dalam Tuturan Lisan Anak Autis.LITERA, 14 (1(, $37-45)$

Sumarti, E. Salamah, U. 2015. Tindak Tutu Direktif Anak autis. LITERA, 16 (2), (282-294)

Veskarisyanti, G. A. 2008. 12 Terapi Anak Autis Paling Efektif dan Hemat: Untuk Autisme, Hiperaktif, dan Retardasi Mental. Yogyakarta: Pustaka Anggrek.

Wijana, I Dewa Putu. 2011. Berkenalan dengan Linguistik. Yogyakarta: A.com Press. 